\begin{abstract}
Iranica
Abstracta Iranica Revue bibliographique pour le domaine irano-aryen

Volume 34-35-36 | 2017

Comptes rendus des publications de 2011-2013
\end{abstract}

\title{
Anna Zernecke. The Lady of the Titles: The Lady of Byblos and the Search for her 'True Name'
}

\section{Astrid Nunn}

\section{(2) OpenEdition}

1 Journals

\section{Édition électronique}

URL : http://journals.openedition.org/abstractairanica/41216

DOI : 10.4000/abstractairanica.41216

ISSN : 1961-960X

Éditeur :

CNRS (UMR 7528 Mondes iraniens et indiens), Éditions de l'IFRI

\section{Référence électronique}

Astrid Nunn, «Anna Zernecke. The Lady of the Titles: The Lady of Byblos and the Search for her 'True Name' », Abstracta Iranica [En ligne], Volume 34-35-36 | 2017, document 98, mis en ligne le 15 juillet 2016, consulté le 26 septembre 2020. URL : http://journals.openedition.org/abstractairanica/41216 ; DOI : https://doi.org/10.4000/abstractairanica.41216

Ce document a été généré automatiquement le 26 septembre 2020.

Tous droits réservés 


\section{Anna Zernecke. The Lady of the Titles: The Lady of Byblos and the Search for her 'True Name'}

\section{Astrid Nunn}

\section{RÉFÉRENCE}

Anna Zernecke. «The Lady of the Titles: The Lady of Byblos and the Search for her 'True Name' ». Die Welt des Orients, 43/2, 2013, p. 226-242.

1 Quel est le vrai nom de la "Baalat Gubal" "Dame de Byblos"? Elle a été identifiée à Astarté, Anat, Aphrodite, Isis et Hathor! S'appuyant sur des catégories sémantiques et sur deux inscriptions giblites dans lesquelles la "Baalat Gubal" a un titre, l'A. est d'opinion que "Baalat Gubal" n'est pas un titre mais bien le vrai nom de la déesse principale de Byblos.

\section{AUTEURS}

\section{ASTRID NUNN}

Université de Munich 